\title{
Xiphidiocercariae from naturally infected Lymnaea columella (Mollusca, Gastropoda) in urban area: morphology and ultrastructure of the larvae and histological changes in the mollusc host
}

\author{
E. Paviotti-Fischer ${ }^{a, b *}$, E. J. Lopes-Torres ${ }^{c}$, M. A. J. Santos ${ }^{\text {, S. S. V. P. B. Brandolini }}$ \\ and J. Pinheiro ${ }^{a}$
}

aÁrea de Biofísica, Departamento de Ciências Fisiológicas, Instituto de Ciências Biológicas e da Saúde, Universidade Federal Rural do Rio de Janeiro - UFRRJ, Rodovia BR 465, Km 07, CEP 23890-000, Seropédica, RJ, Brasil ${ }^{\mathrm{b}}$ Associação Educacional Dom Bosco, Av. Cel. Prof. Antonio Esteves, 1,
Campo de Aviação, CEP 27523-000, Resende, RJ, Brasil

'Faculdade de Ciências Médicas - FCM, Universidade do Estado do Rio de Janeiro - UERJ, Av. Prof. Manoel de Abreu, 444, $5^{\circ}$ andar, Maracanã, CEP 20550-170, Rio de Janeiro, RJ, Brasil

`Área de Histologia e Embriologia, Departamento de Biologia Animal, Instituto de Ciências Biológicas e da Saúde, Universidade Federal Rural do Rio de Janeiro - UFRRJ, Rodovia BR 465, Km 07, CEP 23890-000, Seropédica, RJ, Brasil eÁrea de Biologia, Departamento de Biologia Animal, Instituto de Ciências Biológicas e da Saúde, Universidade Federal Rural do Rio de Janeiro - UFRRJ, Rodovia BR 465, Km 07, CEP 23890-000, Seropédica, RJ, Brasil

*e-mail: eliana.paviottifischer@gmail.com

Received: July 12, 2017 - Accepted: January 19, 2018 - Distributed: August 31, 2019

(With 2 figures)

\begin{abstract}
Urban agriculture is very common in the cities, as Rio de Janeiro and adjacencies, being important as economic activity. However, this practice can create appropriate conditions for establishment and maintenance of life cycle of many parasites. Lymneid snails can act as intermediate hosts of many trematodes species, including those that infect humans and wild and domestic. In the present study, the snail Lymnaea columella was collected from an urban watercress plantations and the morphology of cercariae released by them was analyzed by light and scanning electron microscopy. The specimens were identified as xiphidiocercariae, belonging to the Cercariae Ornatae group, of the order Plagiorchiiformes. Histological examination of the digestive gland of the infected snails revealed the presence of developing sporocysts, with hemocitary infiltration and metaplasia in the epithelial tissue.
\end{abstract}

Keywords: Lymnaeidae, Trematoda, cercariae, histology.

\section{Xifidiocercárias obtidas em Lymnaea columella (Mollusca, Gastropoda) naturalmente infectadas em área urbana: morfologia e ultraestrutura da larva e alterações histológicas do molusco hospedeiro}

\begin{abstract}
Resumo
Agricultura urbana é muito comum nas cidades, como Rio de Janeiro e adjacências, sendo uma importante atividade econômica de subsistência. No entanto, esta prática pode criar condições adequadas para o estabelecimento e manutenção do ciclo de vida de muitos parasitos. Os moluscos limneídeos podem atuar como hospedeiros intermédios de muitas espécies de trematódeos, incluindo aqueles que infectam humanos e animais selvagens e domésticos. No presente estudo, o molusco Lymnaea columella foi coletado de plantações urbanas de agrião e a morfologia das cercárias liberadas por eles foi analisada por microscopia eletrônica de varredura leve e de varredura. As larvas foram identificadas como xifidiocercárias, pertencentes ao grupo das Cercariae Ornatae, Ordem Plagiorchiiformes. Análises histológicas da glândula digestiva dos moluscos infectados evidenciaram esporocistos, com formação de granuloma e metaplasia do tecido epitelial.
\end{abstract}

Palavras-chave: limneídeos, Trematoda, cercária, histologia.

\section{Introduction}

The snails of Lymnaeidae family are known by the reports of many species that act as intermediate hosts of different digenetic trematodes, including species with medical and veterinary (Keiser and Utzinger, 2005; Coelho et al., 2009). Lymnaea columella (Say, 1817) is one of the main snail species, which participates in the life cycle of 
helminthes, and has been reported as intermediate host by trematodes of the families Fasciolidae, Haematoloechidae, Prosthogonimidae, Plagiorchiidae and Echinostomatidae (Olsen, 1974; Abílio and Watanabe, 1998; Carvalho et al., 2001; Pinheiro et al., 2009). Among the cercariae type found in L. columella are the xiphidiocercariae, which is characterized mainly by the presence of a stylet in the anterior end of oral sucker. This type of cercaria belongs to the order Plagiorchiiformes (Olsen, 1974).

These trematodes larvae cause important impacts on their hosts. Tissue changes of the snail host caused by these parasites in different developmental phases have been observed in different organs, including digestive gland, kidneys and ovotestis (Souza et al., 1995; Brandolini and Amato, 2006; Pinheiro et al., 2009). Information on the parasite-host interaction, in turn, can contribute to biological control programmes of both parasite and host populations (Rao et al., 1985; Carvalho et al., 2002; Zakikhani, et al., 2003), and consequently, of diseases related.

Thus, the present study aimed to describe the morphology of cercariae found in naturally infected specimens of L. columela, collected from urban watercress plantations, using light and scanning electron microscopy, and to analyze possible histological changes in parasitized snails.

\section{Material and Methods}

Snails collection - Adult specimens of L. columella were manually collected from irrigation ditches at two watercress plantations, identified as plantations 1 and 2, both located in the Água Santa, Rio de Janeiro City, RJ (longitude $43^{\circ} 18^{\prime} 18^{\prime \prime} \mathrm{W}$ and latitude $22^{\circ} 54^{\prime} 12^{\prime \prime} \mathrm{S}$ ). The three collections occurred from March to December/2007, forming a convenience sample. For malacological identification, aspects of the snails' external morphology, mainly the shell characteristics, were considered, through comparison with the descriptions of Paraense (1983). Because of the lower temperature and greater snail activity, the collections were always made in the early morning (60 specimens from plantation 1 and 20 from plantation 2). The snails were placed in plastic bottles partially filled with local water and transported to the Biophysics Laboratory of the Physiological Sciences Department, Institute of Biological and Health Sciences, Universidade Federal Rural do Rio de Janeiro (UFRRJ), Seropédica, RJ, Brazil.

Cercariae obtaining - The snails were placed individually in 24-hole plates containing distilled water, under a 100-W light bulb, and were examined for 2-4 hours. After this period, the plates were analyzed under stereomicroscope, and the positive snails (those that released cercariae) were identified. The cercariae released were collected with a Pasteur pipette connected to a rubber bulb and placed in glass jars containing AFA fixative (ethanol $70^{\circ} \mathrm{GL}+$ formalin + acetic acid), prepared according to Amato et al. (1991), for observation by light and scanning electron microscopy.

Light microscopy - The fixed larvae were mounted between glass slides and cover slips and observed under an Olympus BX 51 light microscope, using bright field and differential (or Nomarski) interference contrast (DIC), coupled to an Olympus DP12 digital camera. The images were used to obtain the morphological and morphometric data on the cercariae by processing with the iTEM software. The measurements were obtained from at least five cercariae to calculate the means, expressed in micrometers.

Scanning electron microscopy - Fixed larvae were hydrated in a decreasing ethanol series for 15 minutes at each concentration. The material was then washed three times for 15 minutes each in sodium cacodylate buffer $0.1 \mathrm{M}, \mathrm{pH} 7.2$. Afterward, the material was post-fixed in $1 \%$ osmium tetroxide for 5 minutes, and $0.8 \%$ potassium ferrocyanide for 40 minutes, washed again in the same cacodylate buffer. The post fixed material was dehydrated in an increasing ethanol series for 15 minutes at each step and dried by the critical point method using liquid $\mathrm{CO}_{2}$ (CPD Balzers, Balzers Union). The dried material was mounted on metal supports with carbon tape and sputtered with gold (20-25 nm deposited). The prepared samples were observed under a Jeol JSM 5310 scanning electron microscope operating at acceleration of $20 \mathrm{kV}$ and the images were captured with the SemAfore software (Pinheiro et al., 2005).

The cercariae were identified according to Lühe (1909), Olsen (1974) and Faltýnková et al. (2008).

Histology - For histological processing, the snails were fixed with the shell in modified Duboscq-Brasil fluid (Fernandes, 1949). The paraffin blocks were then cut with a microtone to obtain $5-\mu \mathrm{m}$ histological sections.

The sections were mounted on slides, deparaffinized in xylene and stained with hematoxylin and eosin (HE) and also with Gomori's trichrome to stain the collagen fibers (Humason, 1979), covered with glass cover slips in synthetic Canada balsam and observed under an Olympus BX51 microscope equipped with a DIC system, coupled to an Olympus DP 12 digital camera to capture the images.

\section{Results}

Among the snails collected from both farms, only two specimens from plantation 1 released cercariae $(3.3 \%$ of the snails gathered there). These two snails each released a large number of cercariae when stimulated by light.

\subsection{Xiphidiocercariae: light microscopy}

The cercariae are oval, with an evident anterior oral sucker and elongated tail (Figure 1 A, B, C and D). The acetabulum is located in the medial-posterior region of the body (Figure 1A). In the anterior region of the body, the cercariae have a well-developed stylet located above and behind the oral sucker (Figure 1A e B). The primordial genital organs and oral sucker can be seen in a dorsal view of the body of a cercaria (Figure 1C). The tail region contains a tegumental projection forming the fin fold. That membrane starts at the middle third of the tail and reaches to the end of the tail and then projects to the opposite side through its entire final third (Figure 1D). The presence of elongated tails, associated with the presence of fin folds, indicates that the larvae belong to Cercariae Ornatae Group. 


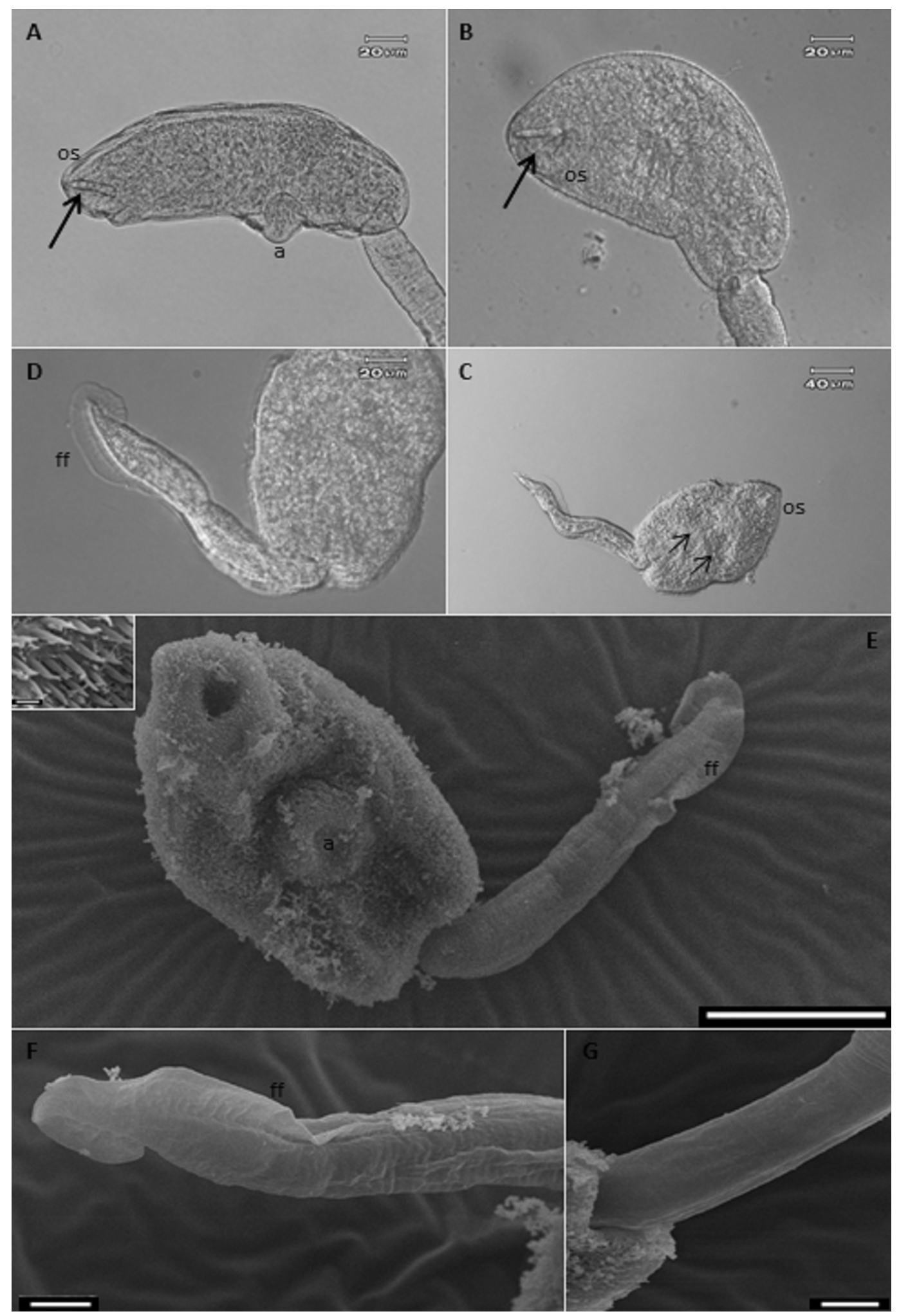

Figure 1. A. Body region with oral sucker (os), acetabulum (a) and stylet (arrow). B. Oral sucker (os) with stylet (arrow). C. Dorsal view of a whole cercaria showing body region with oral sucker (os) and early genital structures (arrows). D. Detail of the tail region with tegumental projection, named the fin fold. E. Whole cercaria showing the acetabulum (a). Inset. Detail of spines located at the edge of oral sucker. F. Cercaria tail with evident fin fold (ff), starting in the midline and projecting to the end of the tail and circumventing the opposite side until the final third. G. Tail insertion. 
Measurements. Body: length 156.4 (132.4-169.4), width 83.0 (69.3-92.4); tail: length 130.3 (89.3-143.2), width 21.93 (21.05 -23.16); oral sucker: diameter 38.8 (28.5-49.3); acetabulum: diameter: 28.1 (24.4-33.3); distance from the oral sucker to the acetabulum 65.2 (61.6-67.7); stylet: length 25.8 (23.1-28.8), width 4.61 (4.11-6.32).

\subsubsection{Xiphidiocercariae: scanning electron microscopy}

The scanning electron microscopy revealed details of the surface topography of the xiphidiocercariae. Besides the structures observable under the light microscope, it was possible to observe a difference in the texture of the body in comparison with the tail. The tegument in the anterior region of the body is covered by spiny structures, while the tail has a smooth surface (Figure 1E and inset). The ventral surface of the body contains openings for the oral suckers at the anterior end, and the acetabulum is located in the medial-posterior region. It was possible to identify the presence of the stylet in the region above the oral sucker, projecting outside the tegument (Figure 1E).

The tail is long, without bifurcation, and contains a projection from the tegument, forming a membranous structure, the fin fold (Figure 1F). The tegument has irregularities, and in some regions striations and small folds can be observed (Figure 1F). The region where the tail and body meet does not present specializations (Figure 1G).

\subsection{Histology}

The infected snails had a large number of sporocysts located in the loose connective tissue. These larvae were enclosed in the connective tissues and presented intense hemocytic infiltration, forming a granuloma-like barrier (Figure 2 A-B).
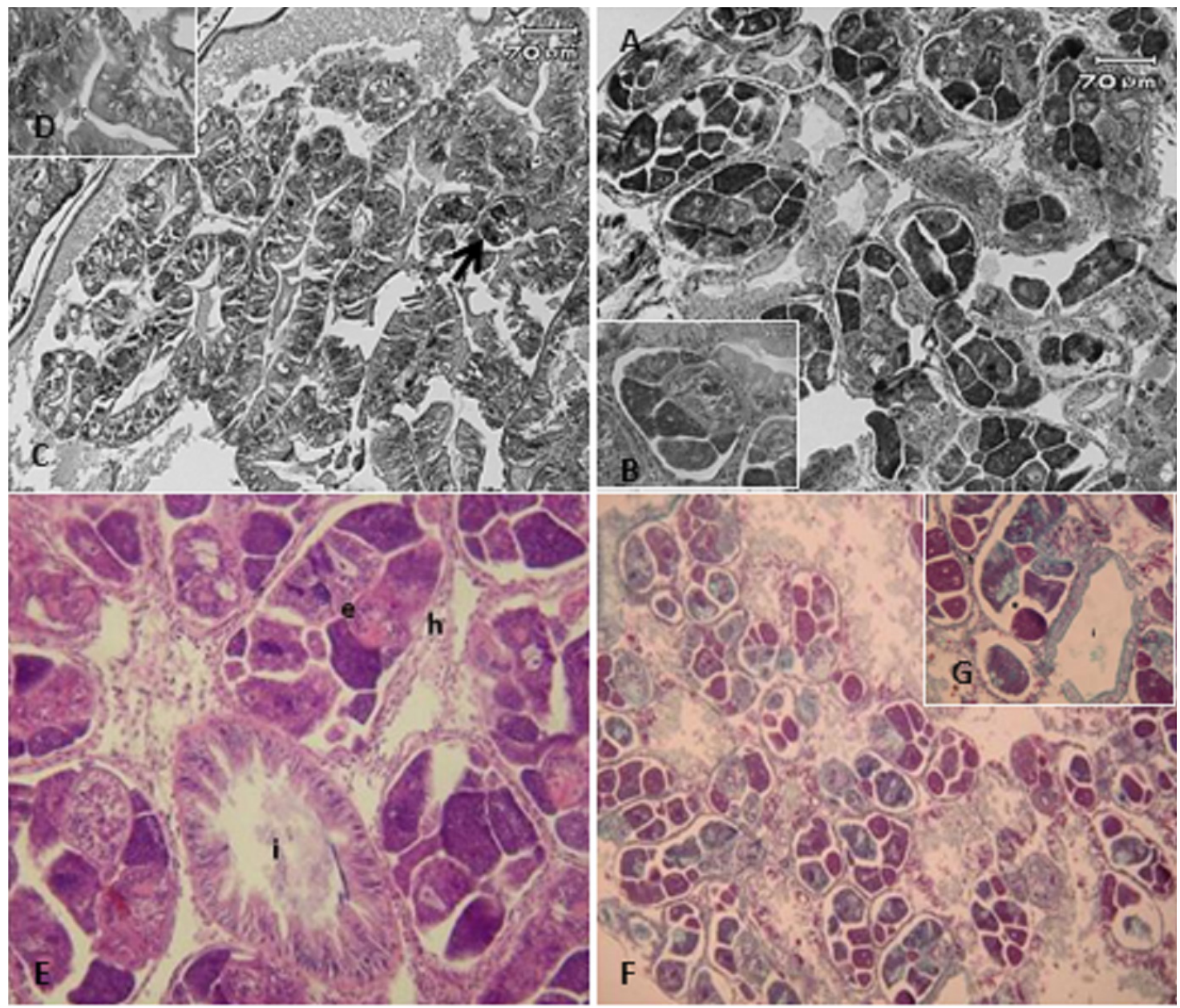

Figure 2. A. A high number of larvae in development in the digestive gland region. B. Detail of a larva in development causing a compression of the acini. C. General view of a digestive gland of an infected snail. D. Folds in the acinar structure, with narrowing of the lumen in the acinus and vacuolation of the cytoplasm. E. Larva (sporocyst - e) in development, showing accumulation of hemocytes (h) around them, where a section of the intestine (i) can also be observed. Stained with hematoxylin-eosin (HE). F. Detail of a sporocyst in development near the intestine (i) region, showing intense hemocyte infiltration, forming a granuloma-like structure surrounding the larvae (40x). G. General view of digestive gland of an uninfected snail, showing a high number of larvae (20x). 
The high presence of parasites in the connective tissue caused compression of the ducts of the digestive glands, in turn causing a change in the epithelial level (Figure 2C). The reduced height of this epithelium led to the formation of folds in the lumen of the ducts, forming papilliferous structures (Figure 2D). It was also possible to observe epithelial desquamation, presence of vacuolated cells and ductal stenosis (narrowing of the lumen).

Intense agglomeration of hemocytes around the developing larvae inside the snails could be observed through staining with Gomori's trichrome (Figure 2E, F and G). This staining also revealed a positive reaction.

\section{Discussion}

\subsection{Xiphidiocercariae}

The stylet is a typical structure of xiphidiocercariae type (Olsen, 1974; Lühe, 1909) and the presence of elongated tails, associated with the presence of fin folds, indicates that the xiphidiocercariae described here belong to the subgroup of the cercariae Ornatae, order Plagiorchiiformes (Olsen, 1974). We believe the stylet is associated with a muscle system, which gives it reversibility, allowing it to project outside the larva's body in the moment of penetration in the vertebrate host, since it was observed in different stages of projection.

The xiphidiocercariae described here is similar to those reported by Carvalho et al. (2001) regarding the proportions between the body and tail size, the length and width of the stylet, and the presence of a tail that presents a densely pleated dorsoventral terminal fin fold. However, the cercariae here observed and described differs from those described by Souza and Melo (2012) and by Boaventura et al. (2002) by being smaller and having a tail shorter than the body. Boaventura et al. (2002) also reported the presence of sensitive papillae, which they called "sensitive hair", laterally to the oral sucker and are evenly distributed to the posterior end of the cercarial body. However, these structures were not observed in our study. Initially, our observations indicate that the cercariae, observed in the present study, are larval trematodes genus Haematolechus. However, in view of the divergences observed, it is more prudent not to carry out identification to the genus level.

In the same place where the snails were collected, adult and larval Odonata, as well as, fishes and amphibians were observed. These animals are reported in literature, respectively, as second intermediate host and definitive host to digentic trematodes of Haematolechus genus, as cited by Boaventura et al. (2002), referring to the xiphidiocercariae from snails collected in the micro region of Rio de Janeiro. Also, Pinto and Melo (2013), which stated that the Xiphidiocercaria larvae are found in freshwater gastropods, being produced in sporocysts, metacercariae are formed mainly in larvae of aquatic insects (Odonata, Diptera, Coleoptera) or in amphibians. In addition, the Ornatae Group cercariae are the only ones whose adults are found parasites of amphibians, the vertebrate host widely distributed in the watercress plantations where the snails were collected in our study.

\subsection{Histology}

The large number of sporocysts in digestive gland of $L$. columella observed in this study also was observe by Carvalho et al. (2001). They also reported that the sporocysts gave origin to xiphidiocercariae.

The formation of a granuloma with intense agglomeration of hemocytes around sporocysts also observed by Souza et al. (1995) in Schistosoma mansoni in Biomphalaria tenagophila and B. straminea. Major changes in the epithelial region of the digestive gland were also observed by Bakry (2009), who reported that infection of snails with $B$. alexandrina with $S$. mansoni miracidia caused great damage in the epithelial region of the host, the cells seemed to be 'empty', secretory cells disappeared and connective tissue was damaged. Probably the author should be referring to the process of vacuolization that occurs in response to the loss of nutrient by the cell as a function of the drainage performed by the developing larvae, such as glycogen.

The presence of collagen fibers around the developing larvae here observed was not observed by Souza et al. (1995) in the granuloma formation in different species of Biomphalaria infected with S. mansoni.

Silva (2003), in his doctoral thesis, also reported the larval development of Echinostoma paraensi (Lie and Basch, 1967) in the digestive gland of L. columella. He observed that the digestive gland presented a disorganized acinar structure, with hypertrophied acini filled with abundant amorphous material and cells with extensive vacuolization.

Brandolini and Amato (2006) also observed sporocysts in the digestive gland of Subulina octona Bruguière, 1792 infected experimentally by Paratanaisia bragai (Santos, 1934). They reported significant destruction of the acini of this gland by sporocysts, along with significant destruction of the digestive gland by metacercariae.

The results obtained in this study confirm that trematode larvae cause significant alterations in their intermediate hosts. The Lymnaeidae as well as the Planorbidae has been incriminated as important host of larvae of trematodes that cause swimmer's itch, which can affect extensive areas of the body of people who have been in contact with water containing infected snails. This ailment has been reported in various places in the United States and Europe (Żbikowska, 2004), but in Brazil there have been no published articles reporting the occurrence of this dermatitis caused by trematode larvae. Nevertheless, the presence of $L$. columella, a snail that is widely distributed throughout Brazil, infected with a trematode whose cercariae can actively penetrate their host brings an alert to the possible occurrence of cases of swimmer's itch caused by penetration of cercariae in non-host humans in the country.

\section{Acknowledgements}

This study was supported by Fundação Carlos Chagas Filho de Amparo à Pesquisa do Estado do Rio de Janeiro (FAPERJ) and Conselho Nacional para o Desenvolvimento Científico e Tecnológico (CNPq). 


\section{References}

ABÍLIO, F.J.P. and WATANABE, T.W., 1998. Ocorrência de Lymnaea columella (Gastropoda: Lymnaeidae), hospedeiro intermediário da Fasciola hepatica, para o estado da Paraíba. Revista de Saude Publica, vol. 32, no. 2, pp. 184-185. http:// dx.doi.org/10.1590/S0034-89101998000200013. PMid:9713125.

AMATO, J.F.R., BOEGER, W.A. and AMATO, S.B., 1991. Protocolos para laboratório coleta e processamento de parasitos do pescado. Seropédica: Universidade Federal Rural do Rio de Janeiro, $81 \mathrm{p}$.

BAKRY, F.A., 2009. Effect of infection with Shistosoma mansoni on some biological parameters in Biomphalaria alexandrina snails. American-Eurasian Journal of Scientific Research, vol. 4, no. 3, pp. 180-190.

BOAVENTURA, M.F., BOAVENTURA, M.F., FERNANDEZ, M.A., THIENGO, S.C., SILVA, R.E. and MELO, A.L., 2002. Formas larvais de Trematoda provenientes de Gastrópodes Límnicos da microrregião Rio de Janeiro, Sudeste do Brasil. Lundiana, vol. 3, pp. 45-49.

BRANDOLINI, S.V.P.B. and AMATO, S.B., 2006. Desenvolvimento larval de Paratanaisia bragai (Santos) (Digenea, Eucotylidae) sob condições experimentais. Revista Brasileira de Zoologia, vol. 23, no. 4, pp. 1097-1100. http://dx.doi.org/10.1590/S010181752006000400017 .

CARVALHO, G.A., ANDRADE, C.F.S. and UETA, M.T., 2002. Experimental infection of Aedes albopictus (Diptera: Culicidae) Larvae with the Xiphidiocercariae of a Hematolechid. Memórias do Instituto Oswaldo Cruz, vol. 97, no. 4, pp. 573-578. http:// dx.doi.org/10.1590/S0074-02762002000400023. PMid:12118294.

CARVALHO, G.A., UETA, M.T. and ANDRADE, C.F.S., 2001. Estudios morfométricos y biológicos de xifidiocercarias (Trematoda) provenientes de la infección natural de Lymnaea columella Say, 1817 (Basommatophora, Lymaenidae) y Biomphalaria tenagophila Orbigny, 1835 (Basommatophora, Planorbidae) recolectados en Miracatu, Estado São Paulo, Brasil. Boletín Chileno de Parasitología, vol. 56, no. 3-4, pp. 1-8.

COELHO, L.H.L., LIMA, W.S. and GUIMARAES, M.P., 2009. Sympatric and allopatric combinations of Lymnaea columella and Fasciola hepatica from southern and south-eastern Brazil. Journal of Helminthology, vol. 83, no. 3, pp. 285-288. http:// dx.doi.org/10.1017/S0022149X09222930. PMid:19243641.

FALTÝNKOVÁ, A., NASINCOVÁ, V. and KABLÁSKOVÁ, L., 2008. Larval trematodes (Digenea) of planorbid snails (Gastropoda: Pulmonata) in Central Europe: a survey of species and key to their identification. Systematic Parasitology, vol. 69, no. 3, pp. 155-178. http://dx.doi.org/10.1007/s11230-007-91271. PMid: 18210216.

FERNANDES, M.C., 1949. Métodos escolhidos de técnicas microscópicas. 2. ed. Rio de Janeiro: Imprensa Nacional.

HUMASON, G.L., 1979. Animal tissue techniques. San Francisco: WH Freeman Co, 661 p.

KEISER, J. and UTZINGER, J., 2005. Emerging foodborne Trematodiasis. Emerging Infectious Diseases, vol. 11, no. 10, pp. 1507-1514. http://dx.doi.org/10.3201/eid1110.050614. PMid:16318688.

LÜHE, M., 1909. Parasitische Plattwürmer I, Trematodes. Die Süsswasserfauna Deutschlands, vol. 17, pp. 1-217.

OLSEN, O.W., 1974. Animal parasites: their life cycles and ecology. 3rd ed. Washington: University Park Press, 562 p.

PARAENSE, W.L., 1983. Lymnaea columella in Northern Brazil. Memorias do Instituto Oswaldo Cruz, vol. 78, no. 4, pp. 477-482. http://dx.doi.org/10.1590/S0074-02761983000400011.

PINHEIRO, J., MALDONADO JÚNIOR, A. and LANFREDI, R.M., 2009. Physiological changes in Lymnaea columella (Say, 1817) (Mollusca, Gastropoda) in response to Echinostoma paraensei Lie and Basch, 1967 (Trematoda: Echinostomatidae) infection. Parasitology Research, vol. 106, no. 1, pp. 55-59. http://dx.doi. org/10.1007/s00436-009-1630-7. PMid:19777261.

PINHEIRO, J., MALDONADO JÚNIOR, A., ATTIAS, M. and LANFREDI, R.M., 2005. Ultrastructure of the miracidium of Echinostoma paraensei Lie \& Basch, 1967 (Trematoda, Echinostomatidae). Parasitology Research, vol. 97, no. 5, pp. 367372. http://dx.doi.org/10.1007/s00436-005-1458-8. PMid:16151745.

PINTO, H.A. and MELO, A.L., 2013. Larvas de trematódeos em moluscos do Brasil: Panorama de perspectivas após um século de estudos. Revista de Patologia Tropical, vol. 42, no. 4, pp. 387-394.

RAO, P.V., BABU, G.R., GURAPPA, K. and KUMAR, A.G., 1985. Larval mosquito control through deployment of xiphidiocercariae. Journal of Invertebrate Pathology, vol. 46, no. 1, pp. 1-4. http:// dx.doi.org/10.1016/0022-2011(85)90122-3. PMid:2863309.

SILVA, J.P., 2003. Morfologia e ultraestrutura dos ovos e estágios larvais de Echinostoma paraensei Lie \& Basch, 1967 (Trematoda: Echinostomatidae) e fisiologia comparada do seu relacionamento com Lymnaea columella Say, 1817 (Mollusca, Gastropoda). Rio de Janeiro: Universidade Federal do Rio de Janeiro, 183 p. Tese de Doutorado em Ciências: Biofísica.

SOUZA, C.P., CUNHA, R.C.P. and ANDRADE, Z.A., 1995. Development of Schistosoma mansoni in Biomphalaria tenagophila, Biomphalaria straminea and Biomphalaria glabrata. Revista do Instituto de Medicina Tropical de Sao Paulo, vol. 37, no. 3, pp. 201-206. http://dx.doi.org/10.1590/S0036-46651995000300004. PMid:8525264.

SOUZA, M.A.A. and MELO, A.L., 2012. Caracterização de larvas de trematódeos emergentes de moluscos gastrópodes coletados em Mariana, Minas Gerais, Brasil. Iheringia, vol. 102, no. 1, pp. 11-18. http://dx.doi.org/10.1590/S0073-47212012000100002.

ZAKIKHANI, M., SMITH, J.M. and RAU, M.E., 2003. Effects of Plagiorchis elegans (digenea: Plagiorchiidae) infection of Biomphalaria glabrata (pulmonata: planorbidae) on a challenge infection with Schistosoma mansoni (digenea: schistosomatidae). The Journal of Parasitology, vol. 89, no. 1, pp. 70-75. http:// dx.doi.org/10.1645/0022-3395(2003)089[0070:EOPEDP]2.0. CO;2. PMid:12659305.

ŻBIKOWSKA, E., 2004. Infection of snails with bird schistosomes and the threat of swimmer's itch in selected Polish lakes. Parasitology Research, vol. 92, no. 1, pp. 30-35. http://dx.doi. org/10.1007/s00436-003-0997-0. PMid:14598171. 